National and Global Petroleum Assessment

\title{
Assessment of Paleozoic Shale-Oil and Shale-Gas Resources in the Tarim Basin of China, 2018
}

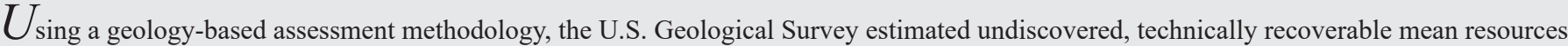
of 1.4 billion barrels of shale oil and 26.9 trillion cubic feet of shale gas in Paleozoic formations in the Tarim Basin of China.

\section{Introduction}

The U.S. Geological Survey (USGS) quantitatively assessed the potential for unconventional (continuous) oil and gas resources within two Paleozoic organic-rich shales in the Tarim Basin of China (figs. 1 and 2): Lower Cambrian Yuertusi Formation and shales in the Middle Ordovician Series. These strata are the principal source rocks for conventional oil and gas fields in the interior of the Tarim Basin (Li and others 2018; Zhu, Chen, and others, 2018).

The Tarim Basin, the largest petroleum basin in China, encompasses 563,000 square kilometers $(\mathrm{km})$, and its Phanerozoic strata are as much as $16 \mathrm{~km}$ thick (Qiu and others, 2012). Although numerous oil and gas fields have been developed along its northern margin and in several uplifts in the basin's interior, large parts of this remote basin remain unexplored. The USGS previously assessed the Tarim Basin's conventional oil and gas resources (Charpentier and others, 2012). Paleozoic marine formations are currently preserved at depth and locally exposed around the basin's periphery. They were deposited on the passive margin of the Tarim craton, a continental fragment proximal to the Gondwana margin. Since the late Paleozoic assembly of Central Asia, the Tarim Basin has been a vast nonmarine basin bounded on the south by the Tibetan Plateau and on the north by the Tien Shan. From the Carboniferous to the present, the basin's margins have been strongly influenced by contractional deformation, including the ongoing Himalayan orogeny. This tectonic history has resulted in a relatively cool geothermal setting throughout the basin's history; the current geothermal gradient is in the range of 20-23 degrees Celsius per km (Zhang, Huang, and others, 2015).

\section{Geologic Background}

The basal Cambrian Yuertusi Formation and the Middle Ordovician deep-marine section (Heituao and Shaergan Formations, for example) include organic-rich black shales with Type II kerogen (Qiu and others, 2012) that represent maximum flooding surfaces in transgressive systems tracts both on the continental slope and in platform sags (Gao and others, 2007). The present total organic carbon (TOC) content of the Cambrian Yuertusi is 7-14 weight percent in outcrops north of the basin, whereas the Middle Ordovician source rocks have TOC contents of $0.5-2.9$ weight percent. The Yuertusi is preserved at depth in the central and eastern part of the basin and is as much as 100 meters $(\mathrm{m})$ thick (Zhu, Chen, and others, 2018). The Middle Ordovician source rocks are similarly distributed with thicknesses of as much as $100 \mathrm{~m}$ (Gao and others, 2007). Thermal maturities ( $R_{0}$ equivalent) of the Yuertusi exceed 4 percent through much of the central part of the basin; $R_{0}$ equivalent values are considerably lower (1-1.5 percent) at the top of the Middle Ordovician in the central part of the basin (Zhang, Liang, and others, 2007; Zhang, Huang, and others, 2015; Zhu, Huang, and others, 2015). Burialhistory models indicate that the Yuertusi was buried to depths sufficient to generate oil by the Ordovician or Silurian Periods (depending on location in the basin) and then oil was cracked to gas in the Mesozoic or Paleogene (Zhang, Huang, and others, 2015; Zhu, Huang, and others, 2015). Late Paleozoic and Mesozoic uplift raised the Ordovician section (in parts of the basin) into the oil-generation window where it has remained through the present day. Oil is preserved in the Ordovician section to depths of at least $7-8 \mathrm{~km}$ in the present Tarim Basin (Zhang, Huang, and others, 2015; Ma and others, 2017).

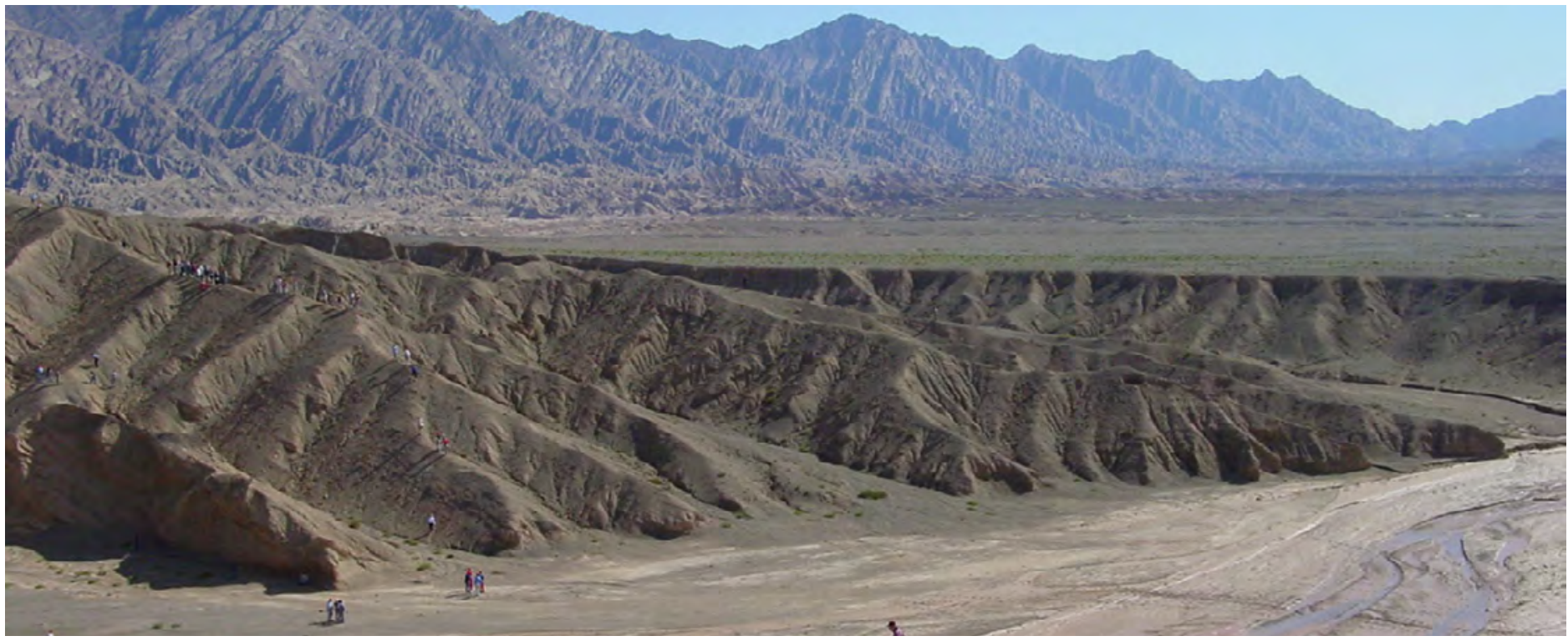

Deformed northern margin of the Tarim Basin and southern foothills of the Tien Shan, China. 


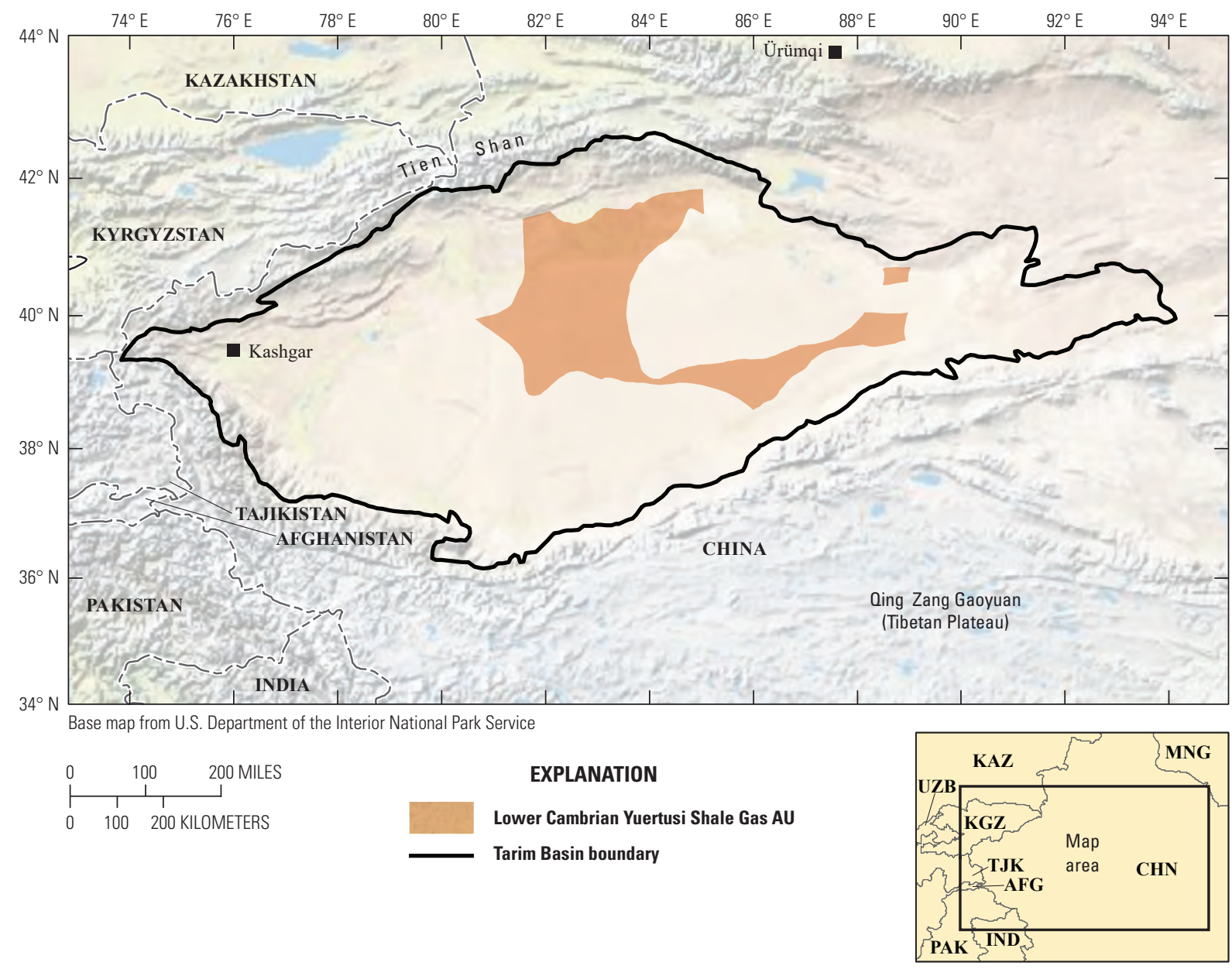

Figure 1. Map showing location of the Tarim Basin, China, and the location of the Lower Cambrian Yuertusi Shale Gas Assessment Unit (AU).

\section{Assessment Units}

We defined three assessment units (AUs) (figs. 1 and 2): Lower Cambrian Yuertusi Shale Gas AU, Ordovician Shale Oil AU, and Ordovician Shale Gas AU. The AUs include only those areas where the organic-rich shale has sufficient thickness (greater than $15 \mathrm{~m}$, the minimum net thickness permitted in USGS screening of international shale-gas and shale-oil resources) (Charpentier and Cook, 2011). In addition, areas where the potential shale reservoirs are deeper than $10 \mathrm{~km}$ are excluded, acknowledging the challenges of hydraulically stimulating wells at those depths. The margins of the basin are excluded from these AUs because they are strongly affected by fold/thrust belts and other faults, greatly increasing the leakage risk and disrupting the continuity of the reservoirs. The Ordovician Shale Oil AU includes those areas where the Middle Ordovician section is less than about $8 \mathrm{~km}$ deep, and the Ordovician Shale Gas AU includes those areas where the Middle Ordovician section is about 8-10 km deep.

The geologic model for the Lower Cambrian Yuertusi Shale Gas AU incorporates oil generation from the organic-rich shale during early to middle Paleozoic voluminous continental-margin sedimentation, followed by preservation of the oil in the source rock through several periods of uplift in the late Paleozoic and Mesozoic Eras, and subsequent cracking of oil to gas during the Mesozoic to early Cenozoic. The presence of Yuertusi-sourced hydrocarbons in shallower conventional accumulations indicates that large volumes of hydrocarbons must have migrated out of the source rock during the basin's evolution, whereas retention of a shale-gas resource in this $\mathrm{AU}$ would require that parts of the shale reservoir were relatively undisturbed by fractures and faults (migration pathways) during the Paleogene to present Himalayan orogeny. Recently, commercial quantities of gas attributed to a Yuertusi source were discovered in a conventional field at 6.9-km depth, higher within the Lower Cambrian Series (Zhu, Huang, and others, 2015; Zhu, Chen, and others, 2018).
The geologic model for the Ordovician Shale Oil AU includes oil generation from organic-rich shale possibly beginning in the Permian but principally occurring in Paleogene time because burial of this unit was interrupted by several periods of uplift in the Paleozoic and Mesozoic Eras. Oil is preserved in the shale source rock at depths as much as $8 \mathrm{~km}$, below which it has likely cracked to gas. The Ordovician Shale Gas AU encompasses the volume of rock in which the oil has cracked to gas, between 8 and $10 \mathrm{~km}$ deep. Success of these Ordovician AUs also depends on the presence of relatively unfractured volumes of self-sourced shale reservoir.

No Paleozoic shale-gas or shale-oil resources have been produced from the Tarim Basin, and we have assigned an AU-level probability of 0.9 to all these AUs (table 1), meaning there is a 10-percent chance that there are no accumulations of the minimum size.

Continuous oil and gas accumulations in the United States were used as analogs in these assessments. Table 1 lists the principal input data used for the assessments.

\section{Undiscovered Resources Summary}

The USGS quantitatively assessed shale-oil and shale-gas resources in Paleozoic strata of the Tarim Basin in China. The estimated mean total for continuous oil resources is 1,373 million barrels of oil (MMBO), or 1.4 billion barrels of oil, with an F95-F5 range from 0 to 3,918 MMBO. The mean total for continuous gas resources is 26,925 billion cubic feet (BCFG), or 26.9 trillion cubic feet, with an F95-F5 range from 0 to $71,946 \mathrm{BCFG}$. The mean total for natural gas liquids is 128 million barrels of natural gas liquids (MMBNGL) with an F95-F5 range from 0 to 361 MMBNGL. These estimates are for undiscovered, technically recoverable resources of oil, gas, and natural gas liquids and do not reflect economically recoverable resources. 


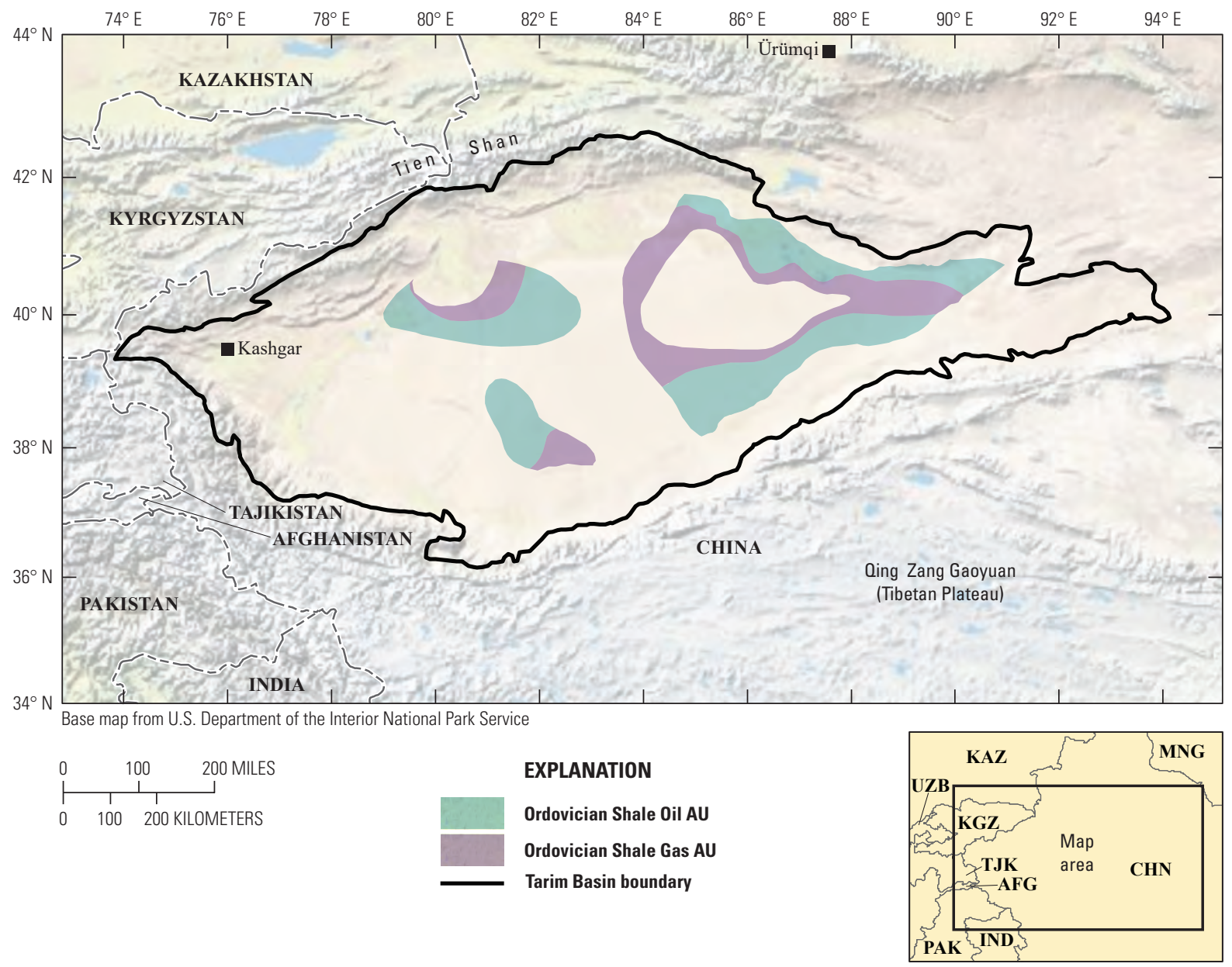

Figure 2. Map showing location of the Tarim Basin, China, and the location of the Ordovician Shale Oil and Ordovician Shale Gas Assessment Units (AUs).

\section{References Cited}

Charpentier, R.R., and Cook, T.A., 2011, USGS methodology for assessing continuous petroleum resources: U.S. Geological Survey Open-File Report 2011-1167, 73 p., accessed May 13, 2014, at https://pubs.usgs.gov/of/2011/1167/OF11-1167.pdf.

Charpentier, R.R., Schenk, C.J., Brownfield, M.E., Cook, T.A., Klett, T.R., Pitman, J.K., and Pollastro, R.M., 2012, Assessment of undiscovered conventional oil and gas resources of six geologic provinces of China: U.S. Geological Survey Fact Sheet 2012-3117, 4 p.

Gao ZhiYong, Zhang ShuiChang, Zhang XingYang, and Zhu RuKai, 2007, Relations between spatial distribution and sequence types of the Cambrian-Ordovician marine source rocks in Tarim Basin: Chinese Science Bulletin, v. 52, supp. 1, p. 92-102.

Li Yun, Xiong Yongqiang, Liang Qianyong, Fang Chenchen, Chen Yuan, Wang Xiaotao, Liao Zewen, and Peng Ping'an, 2018, The application of diamondoid indices in the Tarim oils: American Association of Petroleum Geologists Bulletin, v. 102, no. 2, p. 267-291. [Also available at https://doi.org/ 10.1306/0424171518217073.]

Ma Anlai, Jin Zhijum, Zhu Cuishan, and Bai Zhenrui, 2017, Cracking and thermal maturity of Ordovician oils from Tahe Oilfield, Tarim Basin, NW [northwest] China: Journal of Natural Gas Geoscience, v. 2, no. 4, p. 239-252. [Also available at https:// doi.org/10.1016/j.jnggs.2017.12.001.]
Qiu Nansheng, Chang Jian, Zuo Yinhui, Wang Jiyang, and Li Huili, 2012, Thermal evolution and maturation of lower Paleozoic source rocks in the Tarim Basin, northwest China: American Association of Petroleum Geologists Bulletin, v. 96, no. 5, p. 789-821 [Also available at https://doi.org/10.1306/09071111029.]

Zhang ShuiChang, Liang DiGang, Zhu GuangYou, Zhang XingYang, Zhang BaoMin, Chen JianPing, and Zhang Bin, 2007, Fundamental geological elements for the occurrence of Chinese marine oil and gas accumulations: Chinese Science Bulletin, v. 52, supp. 1, p. 28-43. [Also available at https://doi.org/10.1007/s11434-007-6020-x.]

Zhang Shuichang, Huang Haiping, Su Jin, and Liu Mei, 2015, Ultra-deep liquid hydrocarbon exploration potential in cratonic region of the Tarim Basin inferred from gas condensate genesis: Fuel, v. 160, p. 583-595. [Also available at https://doi.org/ 10.1016/j.fuel.2015.08.023.]

Zhu Guangyou, Chen Feiran, Wang Meng, Zhang Zhiyao, Ren Rong, and Wu Lin, 2018, Discovery of the lower Cambrian high-quality source rocks and deep oil and gas exploration potential in the Tarim Basin, China: American Association of Petroleum Geologists Bulletin, v. 102, no. 10, p. 2123-2151. [Also available at https:// doi.org/10.1306/03141817183.]

Zhu Guangyou, Huang Haiping, and Wang Huitong, 2015, Geochemical significance of discovery in Cambrian reservoirs at Well ZS1 of the Tarim Basin, northwest China: Energy Fuels, v. 29, no. 2, p. 1332-1344. [Also available at https://doi.org/10.1021/ef502345n.] 
Table 1. Key input data for three continuous assessment units (AUs) in the Tarim Basin, China.

[\%, percent; EUR, estimated ultimate recovery per well; MMBO, million barrels of oil; BCFG, billion cubic feet of gas. Well drainage area, success ratio, and EUR are defined partly using U.S. shale-oil and shale-gas analogs. The average EUR input is the minimum, median, maximum, and calculated mean. Shading indicates not applicable]

\begin{tabular}{|c|c|c|c|c|c|c|c|c|}
\hline \multirow{2}{*}{$\begin{array}{l}\text { Assessment input data- } \\
\text { Continuous AUs }\end{array}$} & \multicolumn{4}{|c|}{ Ordovician Shale Oil AU } & \multicolumn{4}{|c|}{ Ordovician Shale Gas AU } \\
\hline & Minimum & Mode & Maximum & Calculated mean & Minimum & Mode & Maximum & $\begin{array}{l}\text { Calculated } \\
\text { mean }\end{array}$ \\
\hline $\begin{array}{l}\text { Potential production area of } \\
\text { AU (acres) }\end{array}$ & 1,000 & $1,000,000$ & $18,700,000$ & $6,567,000$ & 1,000 & $2,000,000$ & $11,597,600$ & $4,532,867$ \\
\hline $\begin{array}{l}\text { Average drainage area of } \\
\text { wells (acres) }\end{array}$ & 60 & 100 & 120 & 93.3 & 40 & 80 & 120 & 80 \\
\hline Success ratio $(\%)$ & 10 & 50 & 90 & 50 & 10 & 50 & 90 & 50 \\
\hline $\begin{array}{l}\text { Average EUR (MMBO, oil; } \\
\text { BCFG, gas) } \\
\end{array}$ & 0.02 & 0.04 & 0.1 & 0.043 & 0.2 & 0.35 & 0.8 & 0.373 \\
\hline AU probability & 0.9 & & & & 0.9 & & & \\
\hline
\end{tabular}

\begin{tabular}{|l|c|c|c|c|}
\hline \multirow{2}{*}{$\begin{array}{c}\text { Assessment input data- } \\
\text { Continuous AU }\end{array}$} & \multicolumn{4}{c|}{ Lower Cambrian Yuertusi Shale Gas AU } \\
\cline { 2 - 5 } & Minimum & Mode & \multicolumn{1}{c|}{ Maximum } & Calculated mean \\
\hline $\begin{array}{l}\text { Potential production area of } \\
\text { AU (acres) }\end{array}$ & 1,000 & $3,000,000$ & $19,653,000$ & $7,551,333$ \\
\hline $\begin{array}{l}\text { Average drainage area of } \\
\text { wells (acres) }\end{array}$ & 40 & 80 & 120 & 80 \\
\hline Success ratio (\%) & 10 & 50 & 90 & 50 \\
\hline Average EUR (BCFG ) & 0.2 & 0.35 & 0.8 & 0.373 \\
\hline AU probability & 0.9 & & & \\
\hline
\end{tabular}

\section{Tarim Basin Assessment Team}

Christopher J. Potter, Christopher J. Schenk, Tracey J. Mercier, Marilyn E. Tennyson, Thomas M. Finn, Cheryl A. Woodall, Heidi M. Leathers-Miller, Kristen R. Marra, Phuong A. Le, Ronald M. Drake II, Michael E. Brownfield, and Janet K. Pitman

\section{For More Information}

Assessment results are also available at the USGS

Energy Resources Program website at https://energy.usgs.gov.

Table 2. Results for three continuous assessment units (AUs) in the Tarim Basin, China.

[MMBO, million barrels of oil; BCFG, billion cubic feet of gas; NGL, natural gas liquids; MMBNGL, million barrels of natural gas liquids. Results shown are fully risked estimates. F95 represents a 95-percent chance of at least the amount tabulated; other fractiles are defined similarly. Fractiles are additive under the assumption of perfect positive correlation. Shading indicates not applicable]

\begin{tabular}{|c|c|c|c|c|c|c|c|c|c|c|c|c|c|c|}
\hline \multirow{3}{*}{$\begin{array}{l}\text { Total petroleum systems } \\
\text { and assessment units (AUs) }\end{array}$} & \multirow{3}{*}{$\begin{array}{c}\text { AU } \\
\text { probability }\end{array}$} & \multirow{3}{*}{$\begin{array}{l}\text { Accumulation } \\
\text { type }\end{array}$} & \multicolumn{12}{|c|}{ Total undiscovered resources } \\
\hline & & & \multicolumn{4}{|c|}{ Oil (MMBO) } & \multicolumn{4}{|c|}{ Gas (BCFG) } & \multicolumn{4}{|c|}{ NGL (MMBNGL) } \\
\hline & & & F95 & $\mathbf{F 5 0}$ & F5 & Mean & F95 & F50 & F5 & Mean & F95 & $\mathbf{F 5 0}$ & $\mathbf{F 5}$ & Mean \\
\hline \multicolumn{15}{|c|}{ Ordovician Total Petroleum System } \\
\hline Ordovician Shale Oil AU & 0.9 & Oil & 0 & 1,032 & 3,918 & 1,373 & 0 & 650 & 2,978 & 959 & 0 & 15 & 77 & 24 \\
\hline Ordovician Shale Gas AU & 0.9 & Gas & & & & & 0 & 7,916 & 25,653 & 9,743 & 0 & 31 & 106 & 39 \\
\hline \multicolumn{15}{|c|}{ Cambrian Total Petroleum System } \\
\hline $\begin{array}{l}\text { Lower Cambrian Yuertusi Shale } \\
\text { Gas AU }\end{array}$ & 0.9 & Gas & & & & & 0 & 13,015 & 43,315 & 16,223 & 0 & 51 & 178 & 65 \\
\hline $\begin{array}{l}\text { Total undiscovered continuous } \\
\text { resources }\end{array}$ & & & 0 & 1,032 & 3,918 & 1,373 & 0 & 21,581 & 71,946 & 26,925 & 0 & 97 & 361 & 128 \\
\hline
\end{tabular}

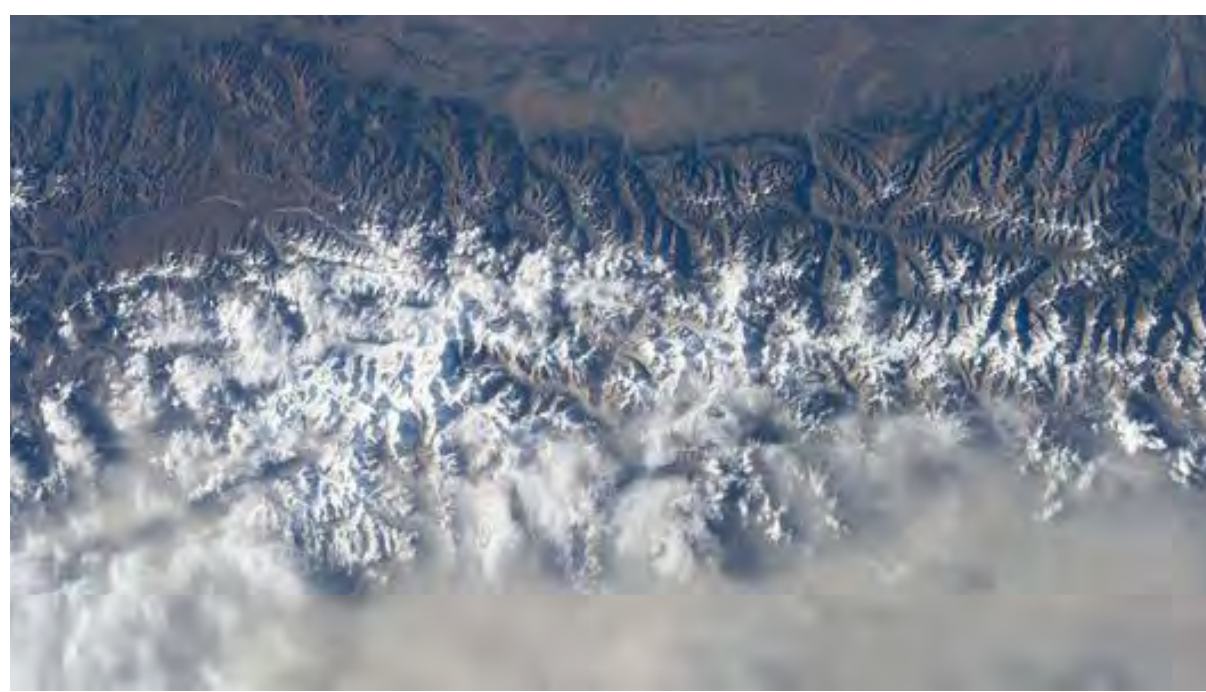

Photograph by Karen Nyberg, an Expedition 36 crew member on board the International Space Station, of the Tien Shan mountain range, central Asia.

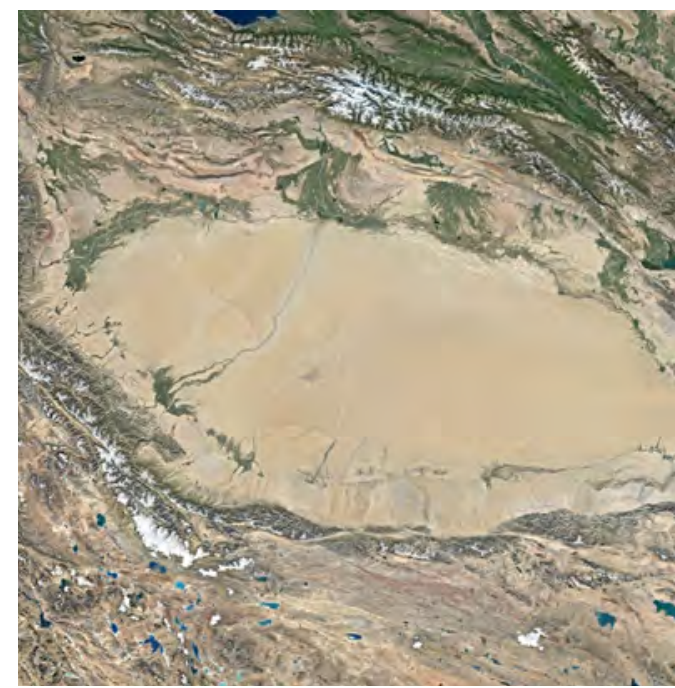

Google Earth image of the Tarim Basin, China, showing about 1,000 kilometers (east-west); base map data from Google, Landsat/Copernicus, 2019. 